\title{
Lactate kinetics during exercise in chronic obstructive pulmonary disease
}

\author{
François Maltais MD, Sarah Bernard BSc, Jean Jobin PhD, \\ Roger Belleau MD, Pierre LeBlanc MD \\ Unité de recherche en pneumologie, Centre de pneumologie de l'Hôpital Laval, and Institut de \\ Cardiologie de Québec, Hôpital Laval, Université Laval, Québec
}

F Maltais, S Bernard, J Jobin, R Belleau, P LeBlanc. Lactate kinetics during exercise in chronic obstructive pulmonary disease. Can Respir J 1997;4(5):251-257.

OBJECTIVES: To examine whether the lactate kinetics during exercise are abnormal in patients with chronic obstructive pulmonary disease (COPD) and to evaluate the relationship of lactate kinetics with functional status.

POPULATION: Fifty-four patients with COPD (forced expiratory volume in $1 \mathrm{~s}\left[\mathrm{FEV}_{1}\right][$ mean $\pm \mathrm{SD}] 36 \pm 12 \%$ predicted, range 19 to 70 ) and 10 healthy, age-matched normal men were included in this study.

INTERVENTION: Each subject performed a stepwise exercise test up to maximal capacity during which five-breath averages of oxygen uptake $\left(\mathrm{VO}_{2}\right)$ were obtained. Arterial plasma lactate $(\mathrm{La})$ concentration was also measured at each one-minute exercise step. The $\mathrm{La} / \mathrm{VO}_{2}$ relationship during exercise was fitted by an exponential function

$$
\mathrm{La}=\mathrm{a}+\mathrm{b}^{\dot{\mathrm{VO}}}{ }_{2}
$$

where $b$ represents the steepness of the relationship. Patients' functional status was classified according to the peak $\mathrm{VO}_{2}$ : more than $16 \mathrm{~mL} / \mathrm{min} / \mathrm{kg}$ and $20 \mathrm{~mL} / \mathrm{min} / \mathrm{kg}$ or less indicated mild to moderate impairment (class $\mathrm{B}, \mathrm{n}=15$ ); more than $10 \mathrm{~mL} / \mathrm{min} / \mathrm{kg}$ and 16 or less $\mathrm{mL} / \mathrm{min} / \mathrm{kg}$, moderate to severe impairment (class $\mathrm{C}, \mathrm{n}=31$ ); and more than $6 \mathrm{~mL} / \mathrm{min} / \mathrm{kg}$ and $10 \mathrm{~mL} / \mathrm{min} / \mathrm{kg}$ or less, severe impairment (class $\mathrm{D}, \mathrm{n}=8$ ). An average $\mathrm{La} / \mathrm{VO}_{2}$ relationship was constructed for each functional class with the $\mathrm{La}$ and $\mathrm{VO}_{2}$ data obtained from each individual at each exercise step.

RESULTS: Parameter b was obtained in all normal subjects and in 46 of 54 patients with COPD. It averaged $2.66 \pm 0.47$ and $4.49 \pm 1.72$ in normal subjects and COPD patients, respectively $(\mathrm{P}<0.005)$. In 30 of 46 patients, parameter $b$ was greater than the upper value obtained in the normal group. The rise in arterial lactate concentration during exercise became progressively greater with the worsening of functional status.

CONCLUSIONS: Lactate kinetics are frequently abnormal in patients with moderate to severe COPD compared with age-matched normal subjects. Reduction in functional status from class B to D was associated with a progressively greater increase in arterial blood lactate during exercise.

Key Words: Chronic obstructive pulmonary disease, Exercise, Lactate

\section{La cinétique des lactates durant l'exercise dans la maladie pulmonaire obstructive chronique}

OBJECTIFS: Évaluer si la cinétique des lactates sanguins durant l'exercice est fréquemment anormale dans la maladie pulmonaire obstructive chronique (MPOC) et si il y a une relation entre celleci et la classe fonctionnelle.

POPULATION: Cinquante-quatre patients atteints de MPOC

voir page suivante 
(VEMS: $36 \pm 12 \%$ pred, moyenne \pm écart-type, écart: $19-70$ ) et 10 sujets sains d'âge comparable ont participé à cette étude.

INTERVENTION: Tout les participants ont subi une épreuve d'effort par paliers progressifs d'une minute pendant lesquels la $\mathrm{VO}_{2}$ et la concentration artérielle des lactates (La) furent mesurées. La relation $\mathrm{La} / \mathrm{V}_{2}$ fut décrite par une équation exponentielle de forme

$$
\mathrm{La}=\mathrm{a}+\mathrm{b}^{\dot{\mathrm{V}} \mathrm{O}_{2}}
$$

ou b représente le taux d'augmentation des lactates. La capacité fonctionnelle des patients fut classée selon la valeur de la $\mathrm{VO}_{2}$ maximale atteinte lors du test à l'effort: $>16$ and $\leq 20 \mathrm{~mL} / \mathrm{min} / \mathrm{kg}$ indiquait une atteinte fonctionnelle légère à modérée (classe $\mathrm{B}$ ), $>10$ and $\leq 16$, une atteinte modérée à sévère (classe $C$ ) et $>6$ and $\leq 10$, une atteinte sévère (classe D). A partir des valeurs individuelles de La et de $\dot{\mathrm{VO}}_{2}$ obtenues à chaque paliers d'effort, une rela- tion $\mathrm{La} / \mathrm{V}_{2}$ moyenne fut construite pour chaque classe fonctionnelle.

RÉSULTATS: Le paramètre b fut obtenu chez tous les sujets normaux et chez $46 / 54$ patients atteints de MPOC. Il était en moyenne de $2.66 \pm 0.47$ et de $4.49 \pm 1.72$, respectivement chez les normaux et les patients $(\mathrm{P}<0.005)$. Le paramètre $\mathrm{b}$ était supérieur à la valeur normale la plus élevée chez 30 des 46 patients MPOC chez qui il a pu être mesuré. L'élévation de la concentration artérielle des lactates était progressivement plus rapide à mesure que la classe fonctionnelle se détériorait.

CONCLUSION: En comparaison avec des individus normaux d'âge similaire, la cinétique des lactates durant l'exercice est fréquemment anormale chez des patients avec MPOC modérée à sévère. Une réduction de la capacité fonctionnelle de la classe $\mathrm{B}$ à $\mathrm{D}$ est associée à une augmentation de plus en plus rapide des lactates sanguins pendant l'exercice.
$\mathrm{I}_{\mathrm{n}}^{\mathrm{n}}$ normal subjects, the amount of blood lactate that accumulates during exercise is related to the intensity of exercise achieved and is a marker of the degree of muscle activation attained (1). Several authors have reported that a significant increase in blood lactate also occurs during exercise in patients with chronic obstructive pulmonary disease (COPD) (2-6), while others have indicated that the onset of lactate increase may occur at relatively low exercise work rates in these individuals $(6,7)$. Because of a lower exercise capacity, the peak lactate achieved in COPD patients is often less than that of normal subjects (8). As a result, the importance of exercise-induced lactic acidosis in exercise limitation in COPD may have been minimized (9).

Using serial lactate concentration measurements during exercise, previous studies have shown that the lactate kinetics are abnormal in COPD patients; for a given submaximal exercise level, the concentration of blood lactate is greater in patients than in normal subjects $(2,8,10,11)$. However, the prevalence of this phenomenon is difficult to evaluate, and it is commonly believed that, because of ventilatory limitation, the vast majority of patients with COPD are unable to exercise sufficiently to activate their skeletal muscles and, thereby, produce a significant amount of lactic acid $(12,13)$. Even if the peak lactate concentration achieved during exercise is lower in COPD than in normal subjects, abnormal lactate kinetics may be important. Increased lactic acidosis for a given exercise work rate places particular stress on the respiratory system. By numerous mechanisms, it results in a greater nonaerobic carbon dioxide production $(14,15)$, enhancing the ventilatory needs while the acidemia may act directly as a breathing stimulus. Abnormal lactate kinetics in patients with COPD might also indicate that the peripheral muscle energy metabolism during exercise is altered in these individuals, with early activation of anaerobic glycolysis $(16,17)$.

This study sought to examine whether lactate kinetics during exercise are commonly abnormal in patients with COPD and to evaluate the possible relationship of lactate kinetics with functional status. Serial arterial lactate concentration measurements were obtained during exercise in 54 COPD patients of varying functional status and in 10 age-matched normal subjects.

\section{Subjects}

\section{PATIENTS AND METHODS}

Fifty-four consecutive patients with COPD evaluated at the exercise physiology laboratory of Hôpital Laval, Ste-Foy, Québe and in whom serial arterial lactate measurements could be obtained during exercise were included in this study. In each case the diagnosis of COPD was based on previous or current smoking history and pulmonary function tests showing moderate to severe irreversible bronchial obstruction (18-20). Patients were clinically stable at the time of the study, and none suffered from cardiovascular, neurological or any other conditions that could impair capacity to perform an exercise test. Ten healthy, nonsmoking males, aged 58 to 70 years, were recruited by means of newspaper advertisement to serve as controls. None of these subjects was involved in a regular exercise program. The institutional ethics committee approved the research protocol, and informed consent was obtained from each patient.

\section{Protocol}

Pulmonary function tests: Standard pulmonary function tests including spirometry, lung volumes and carbon monoxide diffusing capacity of the lungs ( $\mathrm{D}_{\mathrm{L}} \mathrm{CO}$ ) were obtained at baseline according to previously described guidelines (21), and related to normal values of Knudson (18), Goldman and Becklake (19), and Cotes (20), respectively.

Exercise test: After the insertion of an arterial cannula in a radial artery, subjects were seated on an electrically braked cycle ergometer (Quinton Corival 400, A-H Robins, Washington) and connected to the exercise circuit through a mouthpiece. Five-breath averages of oxygen uptake $\left(\dot{\mathrm{VO}}_{2}\right)$ and carbon dioxide output were measured by an automated system equipped with a pneumotachograph, oxygen and carbon dioxide analyzers and a mixing chamber (Quinton Qplex, A-H Robins). After 5 mins of rest, a progressive stepwise exercise test was performed up to the individual's maximum capacity. Each exercise step lasted $1 \mathrm{~min}$, and increments of 10 and 20 watts were used in COPD and normal subjects, respectively. At $1 \mathrm{~min}$ intervals during exercise, dyspnea and leg fatigue perception were rated on a modified Borg scale (22), and arterial blood was sampled for plasma 
TABLE 1

Subjects' characteristics in relation to functional class

\begin{tabular}{|c|c|c|c|c|}
\hline & Class D $(n=8)$ & Class C $(n=31)$ & Class B $(n=15)$ & Normal subjects $(n=10)$ \\
\hline Age (years) & $68 \pm 9$ & $65 \pm 7$ & $65 \pm 5$ & $65 \pm 4$ \\
\hline Sex (Male:Female) & $6: 2$ & $28: 3$ & $13: 2$ & 10:0 \\
\hline Height (m) & $1.61 \pm 0.07$ & $1.68 \pm 0.07$ & $1.65 \pm 0.05$ & $1.68 \pm 0.04$ \\
\hline Weight (kg) & $71 \pm 19$ & $69 \pm 12$ & $73 \pm 15$ & $69 \pm 5$ \\
\hline Hemoglobin $(\mathrm{g} / \mathrm{L})$ & $144 \pm 12$ & $146 \pm 13$ & $146 \pm 11$ & - \\
\hline FEV $_{1}(\mathrm{~L})$ & $0.68 \pm 0.18^{*}$ & $0.92 \pm 0.22^{*}$ & $1.25 \pm 0.35^{\dagger}$ & $2.91 \pm 0.25^{\dagger}$ \\
\hline $\mathrm{FEV}_{1}(\%$ predicted $)$ & $28 \pm 8^{\ddagger}$ & $33 \pm 7^{\ddagger}$ & $48 \pm 14^{\dagger}$ & $104 \pm 8^{\dagger}$ \\
\hline FVC (L) & $1.91 \pm 0.39^{\dagger}$ & $2.56 \pm 0.58^{\S}$ & $2.68 \pm 0.58^{\S}$ & $3.92 \pm 0.44^{\dagger}$ \\
\hline FVC (\% predicted) & $52 \pm 4^{*}$ & $62 \pm 11^{\S}$ & $68 \pm 13^{\S}$ & $93 \pm 8^{\dagger}$ \\
\hline $\mathrm{FEV}_{1} / \mathrm{FVC}(\%)$ & $37 \pm 11^{\ddagger}$ & $36 \pm 7^{\ddagger}$ & $47 \pm 10^{\pi}$ & $75 \pm 7^{\dagger}$ \\
\hline TLC (\% predicted) & $134 \pm 17^{* *}$ & $127 \pm 24^{* *}$ & $121 \pm 18^{\star *}$ & $95 \pm 10^{\dagger}$ \\
\hline $\mathrm{D}_{\mathrm{L}} \mathrm{CO}(\%$ predicted $)$ & $62 \pm 22^{* *}$ & $68 \pm 22^{* *}$ & $85 \pm 20^{* *}$ & $107 \pm 11^{\dagger}$ \\
\hline $\mathrm{PO}_{2}(\mathrm{~mm} \mathrm{Hg})$ & $73 \pm 13^{\ddagger}$ & $77 \pm 8^{\ddagger}$ & $84 \pm 10^{\pi}$ & $95 \pm 13^{\pi}$ \\
\hline Oxygen saturation (\%) & $95 \pm 3^{\ddagger}$ & $96 \pm 2^{* *}$ & $97 \pm 2^{\dagger \dagger}$ & $98 \pm 1^{\ddagger \ddagger}$ \\
\hline $\mathrm{pH}$ & $7.37 \pm 0.03^{\dagger}$ & $7.41 \pm 0.03^{\S}$ & $7.42 \pm 0.03^{\dagger \dagger}$ & $7.44 \pm 0.03^{\text {㧊 }}$ \\
\hline $\mathrm{PCO}_{2}(\mathrm{~mm} \mathrm{Hg})$ & $50 \pm 6^{\dagger}$ & $43 \pm 5^{\dagger \dagger}$ & $41 \pm 4^{\dagger \dagger}$ & 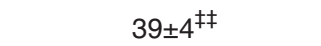 \\
\hline
\end{tabular}

All values are mean $\pm S D$. ${ }^{*} P<0.05$ versus class $D$ or $C$ and $P<0.001$ versus any other group; ${ }^{\dagger} P<0.005$ versus any other group; ${ }^{\ddagger} P<0.05$ versus class $B$ and normal subjects; ${ }^{\S} P<0.05$ versus class $D$ and normal subjects; ${ }^{9} P<0.05$ versus any other group; ${ }^{* *} P<0.05$ versus normal subjects; ${ }^{{ }^{\dagger} P} P<0.05$ versus class $D ;{ }^{; \neq} P<0.005$ versus class $D$ and $C$. DLCO; FEV 1 Forced expiratory volume in 1 s; FVC Forced vital capacity; TLC Total lung capacity

lactate $(\mathrm{La})$ concentration determination. Blood gases were also analyzed at rest and maximal exercise. During the exercise, blood samples were placed on ice and centrifuged at room temperature immediately after termination of the exercise test. Lactate concentrations were measured on plasma with an enzymatic technique (Kit Lactate, Boehringer Mannheim, Mannheim, Germany).

\section{Data analysis}

Lactates kinetics: From the serial measurements of lactate concentrations during exercise, the $\mathrm{La} / \mathrm{VO}_{2}$ relationship was analyzed for each subject as previously described (8). Briefly, an exponential function,

$$
\mathrm{La}=\mathrm{a}+\mathrm{b}^{\mathrm{V}_{2}}
$$

where $a+1$ is the intercept on the $y$ axis and $b$ is a dimensionless parameter describing the steepness of the relationship, was used to fit the experimental data. The curve fitting was constrained so that parameter a could not be smaller than -1 to avoid negative values for La. This model was used because it provided a parameter $b$ from which the steepness of the $\mathrm{La} / \mathrm{V}_{2}$ relationship could be readily compared among individuals. In a previous study the authors found that the $\mathrm{La} / \mathrm{VO}_{2}$ relationship was well fitted by this simple model in patients with COPD (8).

Functional status classification: The functional status was graded according to the $\mathrm{VO}_{2}$ peak using the approach previously used in chronic heart failure by Weber and Janicki (23): greater than $16 \mathrm{~mL} / \mathrm{min} / \mathrm{kg}$ and $20 \mathrm{~mL} / \mathrm{min} / \mathrm{kg}$ or less indicated mild to moderate impairment (class $\mathrm{B}, \mathrm{n}=15$ ), greater than $10 \mathrm{~mL} / \mathrm{min} / \mathrm{kg}$ and 16 or less, moderate to severe impairment (class C, $\mathrm{n}=31$ ), and greater than $6 \mathrm{~mL} / \mathrm{min} / \mathrm{kg}$ and 10 or less, severe impairment (class $\mathrm{D}, \mathrm{n}=8$ ).

Statistical analysis: Values are reported as mean \pm SD unless

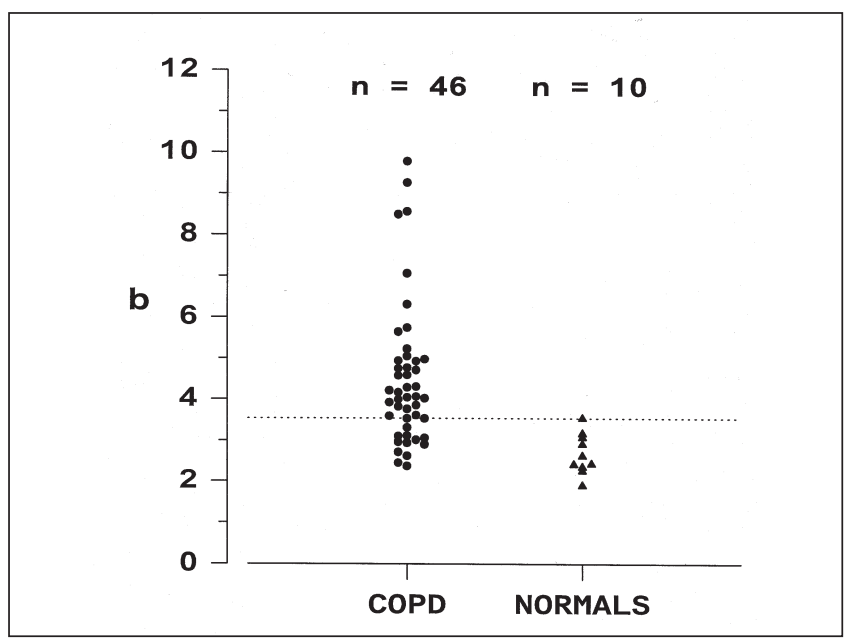

Figure 1) Individual values for parameter $b$ obtained in patients with chronic obstructive pulmonary disease (COPD) and normal subjects. Parameter $b$, which was obtained from the exponential curve fitting of the lactate concentration (La)/oxygen uptake $\left(\mathrm{VO}_{2}\right)$ relationship, describes the steepness of this relationship. Parameter $b$ was significantly greater in COPD patients than in normal subjects (4.49 1.72 versus $2.66 \pm 0.47$, respectively, $P<0.005)$. As indicated by the dotted line, parameter $b$ was greater than the upper value obtained in the normal group in 30 of 46 COPD patients

otherwise stated. The maximal voluntary ventilation (MVV) was estimated by multiplying the forced expiratory volume in $1 \mathrm{~s}\left(\mathrm{FEV}_{1}\right)$ by 35 (24). Comparisons between groups were done using ANOVA and Tukey's comparison test. Parameters obtained from the curve fitting of the $\mathrm{La} / \mathrm{VO}_{2}$ relationships were estimated using an iterative method (MarquardtLevenberg algorithm). Regression analyses were done using the least squares method. $\mathrm{P}<0.05$ was considered statistically significant. 
TABLE 2

Peak exercise data in relation to the functional class

\begin{tabular}{|c|c|c|c|c|}
\hline & Class D $(n=8)$ & Class C $(n=31)$ & Class B $(n=15)$ & Normal subjects $(n=10)$ \\
\hline$\dot{\mathrm{VO}}_{2}(\mathrm{~L} / \mathrm{min})$ & $0.62 \pm 0.14^{*}$ & $0.89 \pm 0.18^{*}$ & $1.31 \pm 0.30^{\dagger}$ & $2.18 \pm 0.40^{\dagger}$ \\
\hline$\dot{\mathrm{V}} \mathrm{O}_{2}(\mathrm{~mL} / \mathrm{min} / \mathrm{kg})$ & $8.7 \pm 0.9^{\dagger}$ & $13.0 \pm 1.5^{\dagger}$ & $18.0 \pm 1.5^{\dagger}$ & $31.7 \pm 6.4^{\dagger}$ \\
\hline$\dot{\mathrm{V}} \mathrm{CO}_{2}(\mathrm{~L} / \mathrm{min})$ & $0.51 \pm 0.11^{*}$ & $0.80 \pm 0.19^{*}$ & $1.30 \pm 0.37^{\dagger}$ & $2.39 \pm 0.48^{\dagger}$ \\
\hline Heart rate (beats/min) & $119 \pm 16^{\ddagger}$ & $128 \pm 15^{\ddagger}$ & $138 \pm 10^{\S}$ & $158 \pm 8^{\dagger}$ \\
\hline Heart rate (\% maximum) & $72 \pm 11^{\ddagger}$ & $76 \pm 9^{\ddagger}$ & $83 \pm 5^{\S}$ & $95 \pm 5^{\dagger}$ \\
\hline VE (L/min) & $22 \pm 5^{\ddagger}$ & $33 \pm 8^{\ddagger}$ & $45 \pm 15^{\S}$ & $93 \pm 26^{\dagger}$ \\
\hline VE/MVV (\%) & $94 \pm 15$ & $107 \pm 21$ & $106 \pm 24$ & $91 \pm 25$ \\
\hline \multicolumn{5}{|l|}{ Borg score } \\
\hline Dyspnea & $7.2 \pm 2.0^{\text {ๆ }}$ & $8.3 \pm 1.6^{\pi}$ & $7.9 \pm 2.2^{\natural}$ & $5.5 \pm 2.0^{\S}$ \\
\hline Leg fatigue & $4.2 \pm 4.3$ & $7.1 \pm 2.6$ & $6.3 \pm 3.0$ & $5.6 \pm 2.8$ \\
\hline $\mathrm{PaO}_{2}(\mathrm{mmHg})$ & $61 \pm 14^{\ddagger}$ & $65 \pm 10^{\pi}$ & $72 \pm 13^{* *}$ & $100 \pm 12^{\dagger}$ \\
\hline Oxygen saturation (\%) & $88 \pm 7^{9}$ & $90 \pm 6^{\pi}$ & $92 \pm 5^{\pi}$ & $98 \pm 1^{\S}$ \\
\hline $\mathrm{pH}$ & $7.32 \pm 0.01$ & $7.34 \pm 0.04$ & $7.32 \pm 0.04$ & $7.35 \pm 0.04$ \\
\hline $\mathrm{PCO}_{2}(\mathrm{mmHg})$ & $56 \pm 5^{\S}$ & $49 \pm 7^{* *}$ & $49 \pm 6^{\star *}$ & $36 \pm 5^{\dagger}$ \\
\hline
\end{tabular}

All values mean $\pm S D$. ${ }^{*} P<0.01$ versus any other group; ${ }^{\dagger} P<0.001$ versus any other group; ${ }^{\ddagger} P<0.05$ versus class $B$ and normal subjects; ${ }^{\S} P<0.05$ versus any other group; ${ }^{9} P<0.05$ versus normal subjects; ${ }^{*} P<0.05$ versus class $D$ and normal subjects. MVV Maximum voluntary ventilation; $\dot{V} \mathrm{O}_{2}$ Oxygen uptake; $\dot{V} \mathrm{CO}_{2}$ Carbon dioxide output; $\dot{V} \mathrm{E}$ Minute ventilation

TABLE 3

Lactate kinetics parameters in relation to the functional class

\begin{tabular}{lllll}
\hline & Class D $(n=8)$ & Class C $(n=31)$ & Class B $(n=15)$ & Normal subjects $(n=10)$ \\
\hline Lactates $(\mathrm{mmol} / \mathrm{L})$ & & & & $0.68 \pm 0.22$ \\
$\quad$ Rest & $0.89 \pm 0.39$ & $0.81 \pm 0.28$ & $0.84 \pm 0.37$ & $7.99 \pm 2.07^{\dagger}$ \\
Peak exercise & $2.15 \pm 0.81^{*}$ & $3.58 \pm 1.28^{*}$ & $4.59 \pm 1.46^{*}$ & $-1.0 \pm 0.0$ \\
Parameter a & - & $-0.9 \pm 0.2$ & $-0.9 \pm 0.3$ & $2.66 \pm 0.47^{\ddagger}$ \\
Parameter b & - & $4.98 \pm 1.82^{\dagger}$ & $3.47 \pm 0.84^{\ddagger}$ & \\
\hline
\end{tabular}

All values mean $\pm S D$. ${ }^{*} P<0.05$ versus any other group; ${ }^{\dagger} P<0.001$ versus any other group; ${ }^{\ddagger} P<0.001$ versus classs $C$ and $P<0.05$ versus class $b$ or normal subjects

\section{RESULTS}

Anthropometric characteristics, pulmonary function and blood gases data for normal subjects and the three functional classes of patients are presented in Table 1. Group mean values for age, weight and height were comparable with each group. In patients, the hemoglobin concentration was within normal range $(160 \pm 20 \mathrm{~g} / \mathrm{L}$ for men in the laboratory); this measurement was not obtained in normal subjects. In patients, deterioration in functional status from class $\mathrm{B}$ to $\mathrm{D}$ was accompanied by a progressive reduction in $\mathrm{FEV}_{1}$ and $\mathrm{PaO}_{2}$, and by the development of resting hypercapnia.

$\mathrm{La} / \mathrm{V}_{2}$ relationship in normal subjects and COPD: The $\mathrm{La} / \mathrm{VO}_{2}$ relationship was fitted by an exponential function in each normal subject and in 46 of 54 COPD patients. The exponential curve fitting was not performed in patients with extremely poor exercise tolerance (class D patients) because only two or three experimental data points could be obtained in these individuals. In normal subjects and COPD patients, the experimental data were well fitted by the exponential function with $\mathrm{r}$ ranging from 0.95 to 0.99 . Parameter a was similar for the two groups averaging $-0.89 \pm 0.24$ and $-1.00 \pm 0.00$ in patients and normal subjects, respectively. The individual values for $b$ are shown in Figure 1. Parameter $\mathrm{b}$ was considerably greater in COPD patients compared with normal subjects $(4.49 \pm 1.72$ versus $2.66 \pm 0.47$, respec- tively, $\mathrm{P}<0.005)$. As indicated by the dotted line, in 30 of 46 patients, parameter $b$ was greater than the upper value obtained in the normal group.

$\mathrm{La} / \mathrm{V}_{2}$ relationship and the functional class: Peak exercise data obtained for normal subjects and each class of patients are reported in Table 2. In normal subjects, peak $\mathrm{VO}_{2}$ amounted to $32 \pm 6 \mathrm{~mL} / \mathrm{min} / \mathrm{kg}$. In patients the response to exercise was characterized by a rapid increase in symptom scores, a reduced or absent ventilatory reserve, oxygen desaturation and carbon dioxide retention. These abnormalities occurred at a gradually lower exercise work rate with the deterioration in functional status.

Group mean values for resting and exercise arterial plasma lactate concentration, and for parameters $\mathrm{a}$ and $\mathrm{b}$ are shown in Table 3. Resting lactate concentrations were similar in normal subjects and patients. Although lactate concentration increased significantly with exercise for each subgroup, the peak lactate concentration achieved was progressively smaller as the functional status worsened. Within each functional class of patients, no significant relationship was found between peak exercise minute ventilaton $(\dot{\mathrm{V} E})$ and plasma lactate concentration. As indicated by parameter $b$, the $\mathrm{La} / \mathrm{VO}_{2}$ relationship became gradually steeper with the reduction in exercise capacity. To appreciate the modification of the $\mathrm{La} / \mathrm{VO}_{2}$ relationship that accompanied the dete- 
rioration in functional status, average $\mathrm{La} / \mathrm{V}_{2}$ relationships were constructed for normal subjects and the three classes of patients (Figure 2). This was done using all individual values for lactate concentration and $\mathrm{VO}_{2}$ obtained at each exercise step. For a given $\mathrm{VO}_{2}$, the lactate concentration increased progressively as the functional status deteriorated.

\section{DISCUSSION}

In this study, the relationship between the arterial lactate concentration and $\dot{\mathrm{VO}}_{2}$ during exercise was obtained in a large group of COPD patients with a wide range of functional status and compared with that of normal subjects of similar age. We found that the increase in lactate was abnormally high in the majority $(70 \%)$ of COPD patients, despite evidence of limitations in ventilation and gas exchange during exercise. In addition, the deterioration in functional status was accompanied by a progressively steeper slope of the $\mathrm{La} /$ $\mathrm{VO}_{2}$ relationship. This may reflect gradual worsening in skeletal muscle oxidative capacity as the functional status and, presumably, the level of daily activity decreased.

The increase in blood lactate concentration during exercise depends on the balance between lactate production and degradation. Although lack of oxygen is not a prerequisite for lactic acid production (25-27), modifying oxygen delivery to the working muscles influences the increase in blood lactate during exercise. Decreasing the oxygen supply by exposing subjects to a hypoxic environment will increase blood lactic acid level $(28,29)$. By contrast, increasing oxygen supply by improving cardiac output during exercise will reduce blood lactic acid level (30). Skeletal muscle metabolic activity also markedly influences lactate production (31-33). It is now suggested that lactate production reflects a balance between glycogen phosphorylase activation and the activity of pyruvate dehydrogenase and oxidative enzymes (33). Finally, a decrease in lactate degradation has also been reported to influence the increase in blood lactate during exercise $(25,34,35)$.

Several factors may have contributed to the greater exercise-induced increase in blood lactate observed in COPD patients. However, several lines of evidence suggest that abnormal lactate kinetics in patients are related to poor skeletal muscle oxidative capacity. In a previous report, we found a significant inverse relationship between the increase in arterial lactate during exercise and aerobic enzyme activities in patients with COPD (8). A similar observation has been reported in chronic heart failure patients, a clinical condition where the oxidative capacity of the skeletal muscle is also reduced (36). Moreover, in 11 patients with COPD involved in a program of exercise training, we reported improvement in skeletal muscle oxidative capacity and reduction in exercise lactic acidosis for a given exercise level (37). Altogether, these studies reinforce the notion that altered skeletal muscle oxidative capacity plays a role in early lactic acid production (36).

Although inappropriately low oxygen delivery, due to exercise-induced right ventricular dysfunction, impaired left ventricular function and/or oxygen desaturation, may have

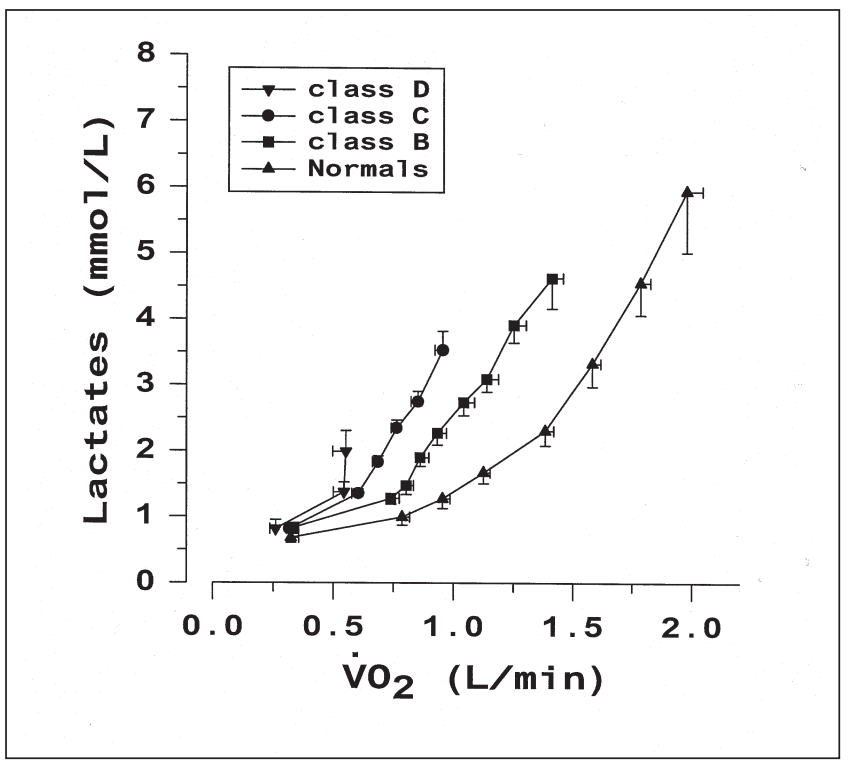

Figure 2) Averaged lactate concentration (La)/oxygen uptake $\left(\dot{V} \mathrm{O}_{2}\right)$ relationships obtained in the three functional classes of patients and normal subjects. For the purpose of clarity, x and y error bars represent $\mathrm{SE}$. The La/VO $\mathrm{O}_{2}$ relationship became progressively steeper with deterioration of the functional status. Class B Patients with peak $\mathrm{VO}_{2}$ greater than $16 \mathrm{~mL} / \mathrm{min} / \mathrm{kg}$ and $20 \mathrm{~mL} / \mathrm{min} / \mathrm{kg}$ or less; Class C Patients with peak $\dot{V} \mathrm{O}_{2}$ greater than $10 \mathrm{~mL} / \mathrm{min} / \mathrm{kg}$ and 16 $\mathrm{mL} / \mathrm{min} / \mathrm{kg}$ or less; Class $D$ Patients with peak $\mathrm{VO}_{2}$ greater than 6 $\mathrm{mL} / \mathrm{min} / \mathrm{kg}$ and $10 \mathrm{~mL} / \mathrm{min} / \mathrm{kg}$ or less

modified the increase in arterial lactic acid in patients, we do not think that these factors played a predominant role. The end-exercise oxygen saturation was similar among the different classes of patients, while the increase in lactate differed markedly. The absence of correlation between oxygen saturation and plasma lactate concentration has also been noted by several authors (3-5). Previous reports have indicated that the increase in cardiac output during exercise is normal in the majority of COPD patients with similar airflow obstruction as those of the present study $(38,39)$. Furthermore, a recent study conducted in our laboratory showed that the increase in leg blood flow during exercise in COPD was comparable with that of age-matched normal subjects and that there was no relationship between blood lactate concentration and peripheral oxygen delivery (unpublished data). Finally, lactate production by the respiratory muscles or reduction in lactate clearance by the liver are unlikely to have contributed significantly to the abnormal lactate kinetics found in patients $(34,40)$.

Exercise intolerance is one of the most devastating consequences of COPD. This has been traditionally attributed to dyspnea and to limitation in ventilation and in gas exchange. Recently, Jones and Killian have shown that for a given level of airflow obstruction, exercise tolerance varies markedly among individuals (41). Although we found a significant decline in mean value of $\mathrm{FEV}_{1}$ from functional class $\mathrm{B}$ to $\mathrm{D}$, we also observed a large overlap of indexes of airflow obstruction between the different functional classes. These observations strongly suggest that other factors are also involved in exercise limitation in COPD. Recent studies have clearly 
shown that peripheral skeletal muscles are compromised in COPD $(8,42,43)$. Decrease in skeletal muscle mass, strength and mitochondrial enzyme activities have been described, and may play an important role in exercise limitation in COPD $(8,42,43)$. Although the mechanisms underlying this peripheral muscle dysfunction have not been well studied, chronic inactivity is probably one of the most important because similar structural and biochemical changes in peripheral muscles have been described in this condition (7).

From this discussion, it can be hypothesized that the deterioration in functional status from normal subjects to class D patients may be associated with a gradual reduction in the level of daily activity and consequently in peripheral skeletal muscle oxidative capacity (7). This, in turn, could account for the increase in $\mathrm{La} / \mathrm{VO}_{2}$ steepness that occurred as functional status decreased. Our study, however, did not address whether abnormal lactate kinetics contribute to a reduction in exercise tolerance or whether they are secondary to declining functional status. Although abnormal lactate kinetics during exercise may be only a marker of poor peripheral muscle function associated with chronic inactivity it could possibly be involved in early exercise termination by increasing the burden on the respiratory system. The clinical importance of this mechanism remains uncertain because no significant re-

\section{REFERENCES}

1. Carlson LA, Pernow B. Studies on the peripheral circulation and metabolism in man. 1. Oxygen utilization and lactate-pyruvate formation in the legs at rest and during exercise in healthy subjects. Acta Physiol Scand 1961;52:328-42.

2. Shuey CB, Peirce AK, Johnson RL. An evaluation of exercise tests in chronic obstructive lung disease. J Appl Physiol 1969;27:256-61.

3. Vyas MN, Banister EW, Morton JW, Grzybowski S. Response to exercise in patients with chronic airway obstruction. II. Effects of breathing 40 percent oxygen. Am Rev Respir Dis 1971;103:401-12.

4. Raffestin B, Excourrou P, Legrand A, Duroux P, Lockhart A. Circulatory transport of oxygen in patients with chronic airflow obstruction exercising maximally. Am Rev Respir Dis 1982;125:426-31

5. Jakobsson PEJ, Jorfeldt L. Blood fuel metabolites at rest and during exercise in patients with advanced chronic obstructive pulmonary disease with and without chronic respiratory failure. Respiration 1990;57:304-9.

6. Casaburi R, Patessio A, Ioli F, Zanaboni S, Donner CF, Wasserman K. Reductions in exercise lactic acidosis and ventilation as a result of exercise training in patients with obstructive lung disease. Am Rev Respir Dis 1991;143:9-18.

7. Casaburi R. Deconditioning. In: Fishman AP, ed. Pulmonary Rehabilitation. New York: Marcel Dekker Inc, 1996:213-30.

8. Maltais F, Simard AA, Simard C, Jobin J, Desgagnés P, Leblanc P. Oxidative capacity of the skeletal muscle and lactic acid kinetics during exercise in normal subjects and in patients with COPD. Am J Respir Crit Care Med 1996;153:288-93.

9. Belman MJ. Exercise in patients with chronic obstructive pulmonary disease. Thorax 1993;48:936-46.

10. Jones NL, Jones G, Edwards RHT. Exercise tolerance in chronic airway obstruction. Am Rev Respir Dis 1971;103:477-91.

11. Karlsson J, Diamunt B, Folkers K. Exercise-limiting factors in respiratory distress. Respiration 1992;59:18-23.

12. Belman MJ. Exercise in chronic obstructive pulmonary disease. Clin Chest Med 1986;7:585-97.

13. Ries AL. The importance of exercise in pulmonary rehabilitation. Clin Chest Med 1994;15:327-37.

14. Beaver WL, Wasserman K, Whipp BJ. Bicarbonate buffering of lactic acid generated during exercise. J Appl Physiol 1986;60:472-86.

15. Jones NL, Heigenhauser GJF. Getting rid of carbon dioxide during exercise. Clin Sci 1996;90:323-35. lationship was found between peak plasma lactate concentrations and $\mathrm{VE}$ within each functional class of patients. However, it is conceivable that the ventilatory response to a given degree of lactic acidosis may vary markedly among individuals (44). Because of this, the lack of correlation between lactate concentration and $\dot{V E}$ does not exclude the possibility that excessive lactate production may be associated with increased ventilatory requirement in some patients. Premature muscle lactic acidosis may also be involved in exercise intolerance in COPD, impairing muscle contractility and contributing to muscle fatigue $(45,46)$.

We conclude that abnormal lactate kinetics are common in COPD patients with a wide range of disease severity and functional impairment. In our patients, reduction in functional status was associated with progressively greater increase in arterial blood lactate during exercise.

ACKNOWLEDGEMENTS: The authors thank Marthe Bélanger, Marie-Josée Breton, and Alexandra Lauzier without whom this study could not have been completed, and Serge Simard for his statistical assistance. Dr Maltais is grateful to his colleagues from the Centre de Pneumologie de l'Hôpital Laval for their support in his research. This study was supported in part by the Fonds de la recherche en santé du Québec and by la fondation JD Bégin. Université Laval.

16. Kutsuzawa T, Shioya S, Kurita D, Haida M, Ohta Y, Yamabayashi H.

${ }^{31} \mathrm{P}-\mathrm{NMR}$ study of skeletal muscle metabolism in patients with chronic respiratory impairment. Am Rev Respir Dis 1992;146:1019-24.

17. Payen JF, Wuyam B, Levy P, et al. Muscular metabolism during oxygen supplementation in patients with chronic hypoxia. Am Rev Respir Dis 1993;147:592-8.

18. Knudson RJ, Slatin RC, Lebowitz MD, Burrows B. The maximal expiratory flow-volume curve. Normal standards, variability and effects of age. Am Rev Respir Dis 1976;113:587-600.

19. Goldman HI, Becklake MR. Respiratory function tests: Normal values at median altitudes and the prediction of normal results. Am Rev Tuberc 1959;79:454-67.

20. Cotes JE, Hall AM. The transfer factors for the lung; normal values in adults. Normal values for respiratory function in man. Torino: Panminerva Medica, 1970:327-43.

21. American Thoracic Society. Standards for the diagnosis and care of patients with chronic obstructive pulmonary disease (COPD) and asthma. Am Rev Respir Dis 1987;136:225-44.

22. Borg G. Psychophysical bases of perceived exertion. Med Sci Sports Exer 1982;14:377-81.

23. Weber KT, Janicki JS. Lactate production during maximal and submaximal exercise in patients with chronic heart failure. J Am Coll Cardiol 1985;6:717-24.

24. Clark TJH, Freedman S, Campbell EJM, Winn R. The ventilatory capacity of patients with chronic airway obstruction. Clin Sci 1969;36:307-16.

25. Stanley WC, Gertz EW, Wisneski JA, Morris DL, Neese RA, Brooks GA. Systemic lactate kinetics during graded exercise in man. Am J Physiol 1985;249:E595-602.

26. Brooks GA. Lactate production under fully aerobic conditions: The lactate shuttle during rest and exercise. Fed Proc 1986;45:2924-9.

27. Graham TE, Saltin B. Estimation of the mitochondrial redox state in human skeletal muscle during exercise. J Appl Physiol 1989;66:561-6.

28. Koike A, Weiler-Ravell D, McKenzie DK, Zanconato S, Wasserman $\mathrm{K}$. Evidence that the metabolic acidosis threshold is the anaerobic threshold. J Appl Physiol 1990;68:2521-6.

29. Hughes RL, Clode M, Edwards RHT, Goodwin TJ, Jones NL. Effect of inspired $\mathrm{O}_{2}$ on cardiopulmonary and metabolic responses to exercise in man. J Appl Physiol 1968;24:336-47.

30. Siskind SJ, Sonnenblick EM, Forman R, Schuer J, Lejemtel TH. Acute substantial benefit of inotropic therapy with amrinone on exercise 
hemodynamics and metabolism in severe congestive heart failure. Circulation 1981;64:966-73.

31. Saltin B, Gollnick PD. Skeletal muscle adaptability: significance for metabolism and performance. In: Peachy LD, ed. The Handbook of Physiology. Bethesda: American Physiological Society, 1982:555-631.

32. Ivy JL, Withers RT, Van Handel PJ, Elger DH, Costill DL. Muscle respiratory capacity and fiber type as determinants of the lactate threshold. J Appl Physiol 1980;48:523-47.

33. Putman CT, Jones NL, Lands LC, Bragg TM, Hollidge-Horvat MG, Heigenhauser GJF. Skeletal muscle pyruvate dehydrogenase activity during maximal exercise in humans. Am J Physiol 1995;269:E458-68

34. Goodnight-White SJ, Miller CC, Haber SE, Klein PD, Fletcher EC. Lactate kinetics in severe COPD. Implications of an abnormal aminopyrine breath test. Chest 1992;101:268S-73S.

35. Casaburi R, Oi S. Effect of liver disease on the kinetics of lactate removal after heavy exercise. Eur J Appl Physiol 1989;59:89-97.

36. Sullivan MJ, Green HJ, Cobb FR. Altered skeletal muscle metabolic response to exercise in chronic heart failure. Relation to skeletal muscle aerobic enzyme activity. Circulation 1991;84:1597-607.

37. Maltais F, Leblanc P, Simard C, et al. Skeletal muscle adaptation to endurance training in patients with chronic obstructive pulmonary disease. Am J Respir Crit Care Med 1996;154:442-7.

38. Light RW, Mintz HM, Linden GS, Brown SE. Hemodynamics of patients with severe chronic obstructive pulmonary disease during progressive upright exercise. Am Rev Respir Dis 1984;130:391-5.
39. Marciniuck DD, Gallagher CG. Clinical exercise testing in chronic airflow limitation. Med Clin North Am 1996;80:565-87.

40. Engelen MPKJ, Casaburi R, Rucker R, Carithers E. Contribution of the respiratory muscles to the lactic acidosis of heavy exercise in COPD. Chest 1995;108:1246-51.

41. Jones NL, Killian KJ. Limitation of exercise in chronic airway obstruction. In: Cherniack NS, ed. Chronic Obstructive Pulmonary Disease. Philadelphia: WB Saunders, 1991:196-206.

42. Gosselink R, Troosters T, Decramer M. Peripheral muscle weakness contributes to exercise limitation in COPD. Am J Respir Crit Care Med 1996;153:976-80.

43. Schols AMWJ, Soeters PB, Mostert R, Pluymers RJ, Wouters EFM. Physiologic effects of nutritional support and anabolic steroids in patients with chronic obstructive pulmonary disease. A placebo-controlled randomized trial. Am J Respir Crit Care Med 1995; $152: 1268-74$

44. Casaburi R. Exercise training in chronic obstructive lung disease. In: Casaburi R, Petty TL, eds. Principles and Practice of Pulmonary Rehabilitation. Philadelphia: WB Saunders Company, 1993:204-24

45. Mainwood GW, Renaud JM. The effect of acid-base balance on fatigue of skeletal muscle. Can J Physiol Pharmacol 1985;63:403-16.

46. Hultman E, Carale S, Sjoholm H. Effect of induced metabolic acidosis on intracellular $\mathrm{pH}$, buffer capacity and contraction force human skeletal muscle. Clin Sci 1985;69:505. 


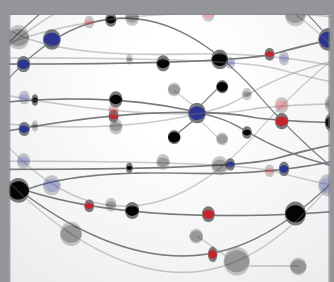

The Scientific World Journal
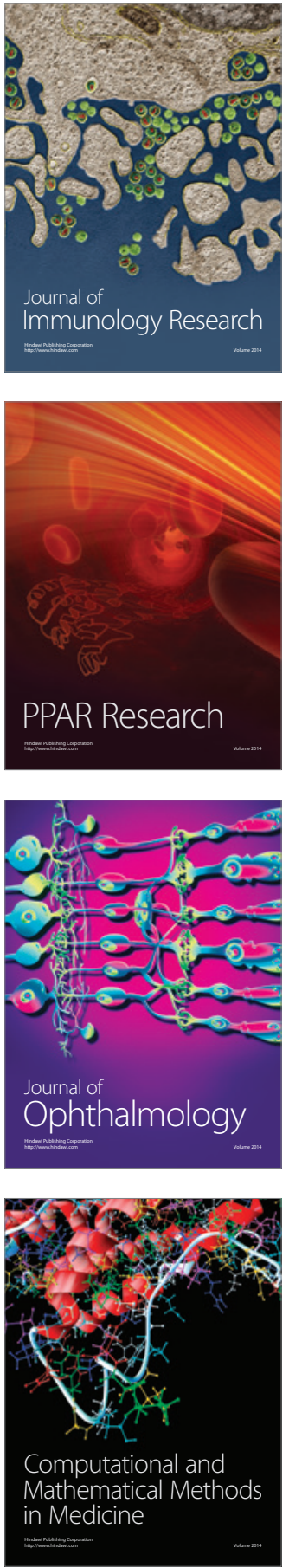

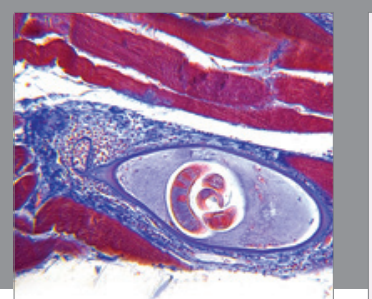

Gastroenterology Research and Practice

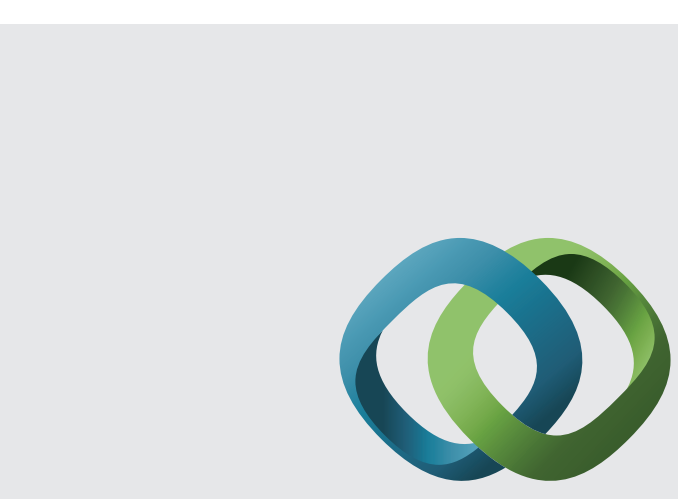

\section{Hindawi}

Submit your manuscripts at

http://www.hindawi.com
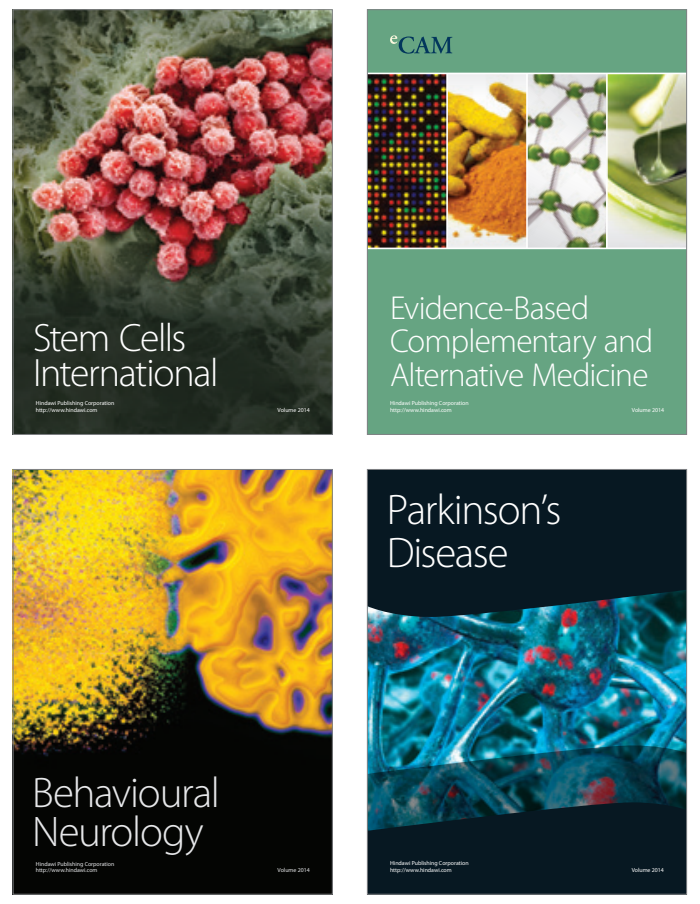
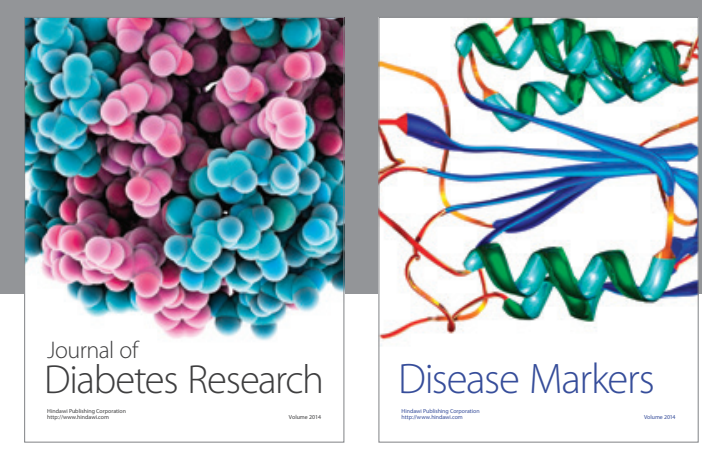

Disease Markers
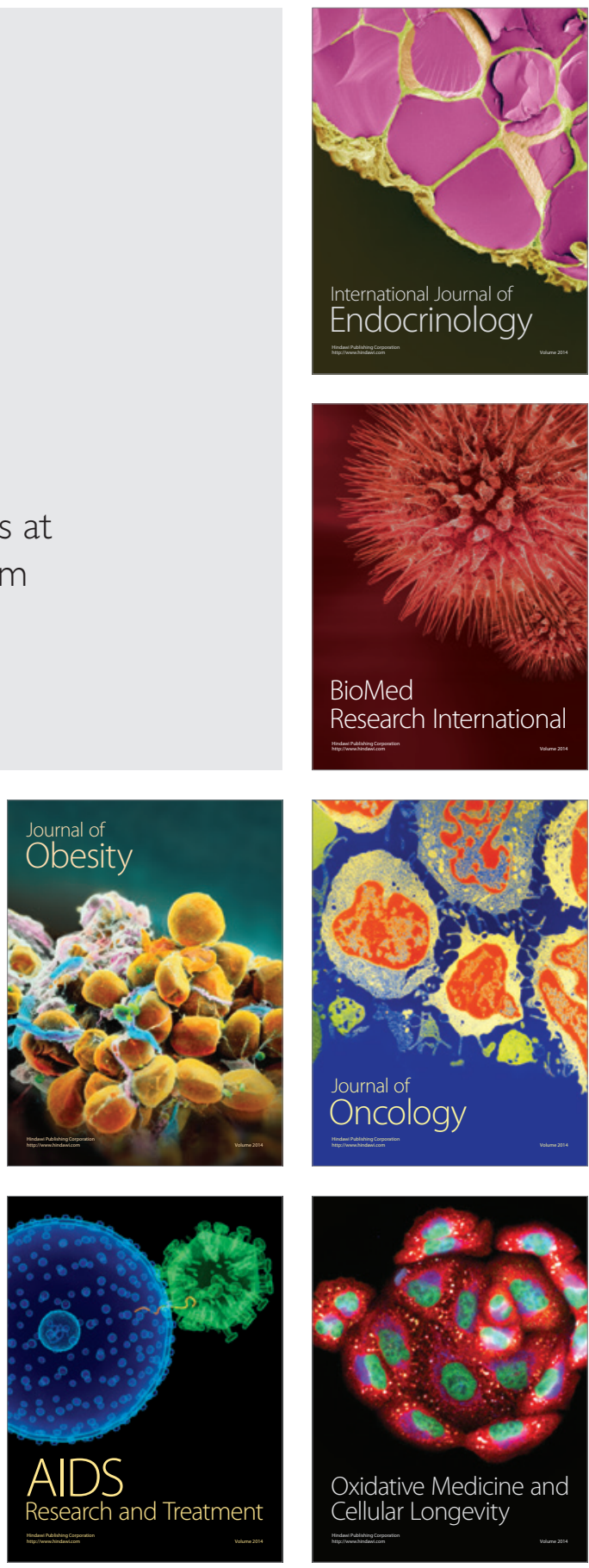